\title{
Analíticas de aprendizaje en educación superior: una revisión de la literatura científica de impacto
}

\section{Learning analytics in higher education: a review of impact scientific literature}

Pilar Cáceres Reche. Universidad de Granada. caceres@ugr.es

\section{Antonio-Manuel Rodríguez-García. Universidad de Granada. arodrigu@ugr.es \\ Gerardo Gómez García. Universidad de Granada. gerardo acci@hotmail.com}

Carmen Rodríguez Jiménez. Universidad de Granada. rodri96@correo.ugr.es

\section{RESUMEN.}

Las analíticas de aprendizaje pueden definirse como una serie de técnicas para recopilar, analizar y otorgar datos procesables y generados por parte de los estudiantes con el objetivo de elaborar estrategias adecuadas para mejorar los procesos de aprendizaje, el rendimiento de los alumnos o el de la propia institución. Este tipo de técnicas son especialmente útiles para establecer patrones de acción que guíen y orienten el proceso educativo en educación superior. Bajo estas premisas, la presente investigación tiene por objetivo analizar la producción científica de mayor impacto sobre el empleo de analíticas de aprendizaje en educación superior. Para ello se ha seguido una metodología cuantitativa atendiendo diez variables: año de publicación, publicaciones periódicas, autores, instituciones, países, tipo de documento, formato de publicación, área de publicación, idioma y artículos más citados. Los resultados proyectan una tendencia de investigación que se encuentra totalmente en auge, especialmente por la mayor producción científica ocurrida en los últimos años (2015-2018) destacando países como Australia, Estados Unidos y Reino Unido. Las publicaciones, en su gran mayoría, proceden de conferencias y se encuentran publicadas en inglés. Destacan las áreas de conocimiento de Ciencias Computacionales y Ciencias Sociales.

\section{PALABRAS CLAVE.}

Analíticas de aprendizaje, universidad, educación superior, bibliometría, Scopus, productividad científica. 


\section{ABSTRACT.}

Learning analytics can be defined as a series of techniques for collecting, analyzing and granting processable data generated by students. Their objective is to develop appropriate strategies to improve the learning processes, the performance of the students or that of the institution itself. These types of techniques are especially useful to establish patterns of action that guide and guide the educational process in higher education. Under these premises, the present research aims to analyze the scientific production with the greatest impact on the use of learning analytics in higher education. For this purpose, a quantitative methodology has been followed, based on ten variables: year of publication, periodicals, authors, institutions, countries, type of document, publication format, publication area, language and most cited articles. The results project a research trend that is fully on the rise, especially due to the greater scientific production that has occurred in recent years (20152018), highlighting countries such as Australia, the United States and the United Kingdom. The publications, in their great majority, come from conferences and are published in English. The knowledge areas of Computational Sciences and Social Sciences stand out.

\section{KEY WORDS.}

Learning analytics, university, higher education, bibliometrics, Scopus; scientific production.

\section{Introducción.}

Education is one of the main axes of any society. For this reason, it has always been one of the most debated and criticized fields over the years (Moreira, Bates y Mota, 2019). During the last years, it has struggled to conquer a process of reconversion of the roles of the people who inhabit the institutions; bet on organizational structures more flexible, open, participatory, communicative; the introduction of new methodologies and resources to improve learning and the quality of training; among other (Hinojo-Lucena et al., 2018; Alonso-García, Rodríguez-García \& Cáceres-Reche, 2018; Montgomery et al., 2019). The objective is not other than to adapt education and the education system to the society of the 21st century.

However, the truth is that education is currently in a period of crisis (Chiape y Rodríguez, 2017). The investigations speak of a disinterest on the part of the students regarding their teaching-learning process (Ulstad, Halvari \& Deci, 2018; Klein, Lester, JRangwala \& Johri, 2019). Therefore, researchers and experts in this field ask ourselves: what is wrong with our educational system? What can you do about it? What happens inside the classrooms? What information can be used to improve?

Although it is true that we deal with difficult questions, from the information and knowledge society, where technology is ubiquitous, there has been talk of an emerging trend for higher education known as "Learning Analytics" (Gedrimiene et al., 2019; Jhonson et al., 2016). Through it, it is easier for institutions to increase their understanding of the needs of their students. In this way, what is intended is that they can use this information to develop strategies that improve and positively influence student learning, thus improving the quality of the process (Yousef, Chatti, Schroeder \& Wosnitza, 2014; Wong \& Li, 2019) and the 
results obtained in it (Antelm, Gil, Cacheiro y Pérez, 2018; Cabedo, Galan \& Gomez, 2017; Mingorance, Trujillo, Caceres \& Torres, 2017).

On the one hand, Slade y Prinslo (2013) define learning analytics "as the collection, analysis, use, and appropriate dissemination of student-generated, actionable data with the purpose of creating appropriate cognitive, administrative, and effective support for learners" (p.1512). On the other hand, learning analytics is defined as "the measurement, collection, analysis, and reporting of data about learners and their contexts, for purposes of understanding and optimizing learning and the environments in which it occurs" (Long \& Siemens, 2014, p. 132).

In this way, through them we obtain the analysis and visualization of a large amount of data (big data) that will allow us to have more information about the situation and make more effective decisions (Huda et al., 2018). Picciano (2012) define big data as "a generic term that assumes that the information or database system(s) used as the main storage facility is capable of storing large quantities of data longitudinally and down to very specific transactions"(p.12). Among them we can highlight: califications, attendance to courses, percentage of graduates, access to learning platforms, interventions, messages, etc.

Picciano (2012) said that "Big data concepts and analytics can be applied to a variety of higher education administrative and instructional applications, including recruitment and admissions processing, financial planning, donor tracking, and student performance monitoring" (p.13).

Refering to Macfadyen \& Dawson (2012) learning analytics provide higher education with highly valuable information to achieve educational excellence. Learning management systems (LMS) offer a large amount of information and usage patterns whose analysis can influence the improvement of student learning outcomes.

There are other authors who judge it from another perspective. Due to the characteristics of the stored data, there are also those who have their doubts and judge whether this practice is really ethical (Siemens, 2012), because the ownership of this data and the right of privacy of students are questioned (Slade \&Prinsloo, 2013). For these reasons, until now, the data is currently restricted for the access of a few. In fact, according to the research of Picciano (2012), only some universities are using this type of techniques.

We can consider, then, that research on learning analytics in higher education is an emerging field that is still poorly researched (Chiape \& Rodríguez, 2017). For this reason, to situate the reader, with the following article is intended to draw a general outline on the research landscape that concerns learning analytics and higher education in the international arena.

\section{Methodology.}

This research aims to analyze the scientific production with the greatest impact on the use of learning analysis in higher education, following the steps of other similar research (LópezMeneses, Vázquez-Cano y Román, 2015; Mengual-Andrés, Vázquez-Cano y LópezMeneses, 2017; Rodríguez-García, Cáceres \& Alonso, 2018). For this, a systematic review of bibliographic studies has been carried out (Hernández Sampieri, Fernández Collado y Baptista Lucio, 2016) given its suitability to respond to investigations of this type. At the

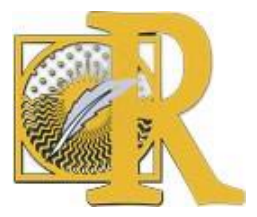


same time, quality indicators considered essential for studies of systematic reviews have been taken into consideration (Urrutia y Bonafill, 2010).

For this purpose, ten variables have been selected:

Table 1: Study variables

\begin{tabular}{|c|}
\hline Year of publication \\
\hline Journal or resource \\
\hline Authors \\
\hline Institution \\
\hline Coiuntry \\
\hline Resource type \\
\hline Publication format \\
\hline Subject area \\
\hline Language \\
\hline Most cited papers \\
\hline
\end{tabular}

To this end, the publications indexed in the Scopus database (Elsevier) have been taken as reference; of collected international prestige. Subsequently, the most suitable keywords that responded to our research objective were selected through ERIC Thesaurus: "learnyng analytic(s)" y "higher education"/ "university".

The search date began in September 2018 and ended in November 2018; At that time, a second search was carried out to guarantee the inclusion of those results that, due to some casuistry, had not been present in the initial explorations. The equation and field of the search were the following:

Table 2: Search operation

\begin{tabular}{|c|}
\hline "Learning analytic" OR "Learning analytics" AND “Higher education" \\
\hline "Learning analytic" OR “Learning analytics" AND “University" \\
\hline
\end{tabular}

Table 3: Search field.

\begin{tabular}{|c|c|}
\hline Database & Search field \\
\hline Scopus & Article title, Abstract, Keywords \\
\hline
\end{tabular}

Finally, in order to publicize the most relevant results that provide an accurate view of the greatest impact on scientific production on learning analytics in education, the following inclusion criteria were established (Table 4). 
Table 4: Inclusion criteria.

\begin{tabular}{|l|l|}
\hline \multicolumn{1}{|c|}{ Variable } & \multicolumn{1}{c|}{ Criteria } \\
\hline Year of publication & All investigations are considered \\
\hline Journal or resource & Five or more references about the topic \\
\hline Authors & Six or more references about the topic \\
\hline Institution & Six or more references about the topic \\
\hline Coiuntry & Six or more references about the topic \\
\hline Resource type & All investigations are considered \\
\hline Publication format & All investigations are considered \\
\hline Subject area & All investigations are considered \\
\hline Language & All investigations are considered \\
\hline Most cited papers & Ten most cited papers \\
\hline
\end{tabular}

\section{Results.}

The search resulted in the extraction of 821 results, through the two combined searches (Table 5):

Table 5: Results.

\begin{tabular}{|c|c|}
\hline Combination & Scopus \\
\hline "Learning analytic" OR “Learning analytics” AND “Higher education” & 332 \\
\hline "Learning analytic" OR “Learning analytics" AND “University” & 489 \\
\hline
\end{tabular}

In the following graph we can see the percentage of each of the combined searches with respect to the total of the analyzed references.

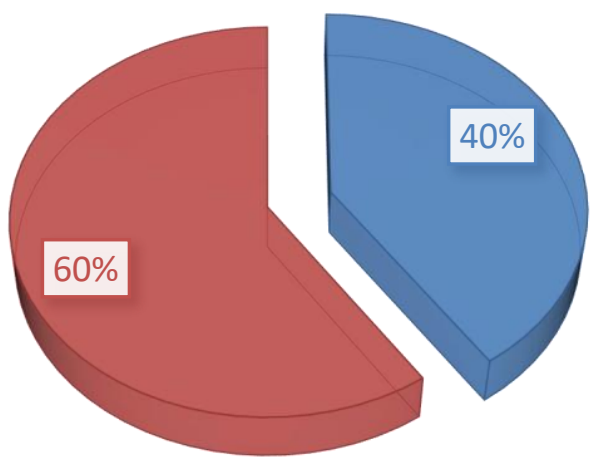

Higher Education

University

Figure 1. Percentage of references based on the search equation used. 
On the other hand, the indexation of the first research on learning analytics in the field of higher education occurred in 2010. However, the highest scientific production begins to occur from 2012, as we can see in the following graphic:

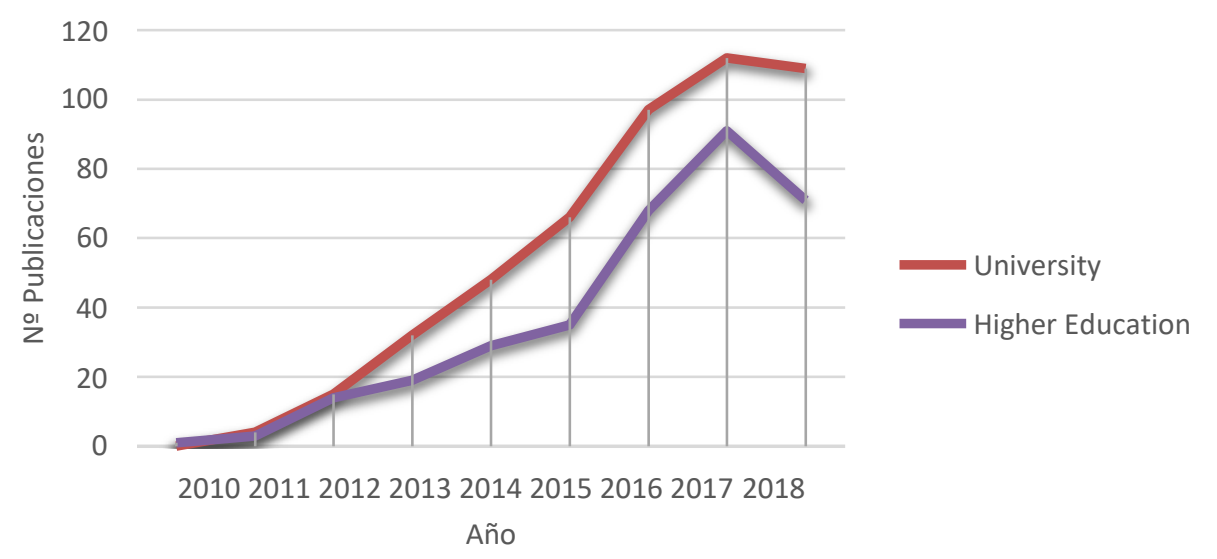

Figure 2. Evolution of research on learning analytics in Higher Education.

Continuing with the results, within the periodic publications variable we find 21 titles that agglutinate 330 investigations (40.2\%) of the 821 analyzed; being all these who have published more on the subject.

Table 6: Periodic publications.

\begin{tabular}{|l|c|c|c|}
\hline \multicolumn{1}{|c|}{ Periodic publications } & \multicolumn{2}{c|}{ Combination } & \\
\cline { 2 - 4 } & $\begin{array}{c}\text { L.A.+ Higher } \\
\text { Education }\end{array}$ & $\begin{array}{c}\text { L.A. + } \\
\text { University }\end{array}$ & Total \\
\hline ACM International Conference Proceeding Series & 48 & 59 & 107 \\
\hline Behaviour And Information Technology & 5 & - & 5 \\
\hline $\begin{array}{l}\text { Big Data And Learning Analytics In Higher Education Current } \\
\text { Theory And Practice }\end{array}$ & 7 & - & 7 \\
\hline Ceur Workshop Proceedings & 7 & 30 & 37 \\
\hline Communications In Computer And Information Science & 8 & - & 8 \\
\hline Computers In Human Behavior & 6 & 11 & 17 \\
\hline Data In Brief & - & 6 & 6 \\
\hline Educational Technology Research And Development & 5 & 8 & 10 \\
\hline IEEE Global Engineering Education Conference Educon & - & 9 & 9 \\
\hline IFIP Advances In Information And Communication Technology & - & 7 & 7 \\
\hline International Journal Of Emerging Technologies In Learning & - & 7 & 7 \\
\hline International Review Of Research In Open And Distance Learning & 5 & - & 5 \\
\hline Internet And Higher Education & - & 6 & 6 \\
\hline Journal Of Asynchronous Learning Network & 5 & - & 5 \\
\hline Lecture Notes In Computer Science Including Subseries Lecture & 27 & 24 & 51 \\
Notes In Artificial Intelligence And Lecture Notes In Bioinformatics & & & \\
\hline Open Learning & - & 8 & 8 \\
\hline Proceedings Frontiers In Education Conference Fie & - & 9 & 9 \\
\hline
\end{tabular}




\begin{tabular}{|l|c|c|c|}
\hline \multicolumn{1}{|c|}{ Periodic publications } & \multicolumn{2}{c|}{ Combination } & \\
\cline { 2 - 4 } & $\begin{array}{c}\text { L.A. A. + Higher } \\
\text { University }\end{array}$ & Total \\
\hline $\begin{array}{l}\text { Proceedings Of The European Conference On E } \\
\text { Learning Ecel }\end{array}$ & - & 6 & 6 \\
\hline Smart Innovation Systems And Technologies & - & 5 & 5 \\
\hline Technology Knowledge And Learning & 8 & 7 & 15 \\
\hline Total & 131 & 199 & 330 \\
\hline
\end{tabular}

Regarding the variable that analyzes the authors with the highest scientific production on this research focus, in the following table we present those that have indexed 6 or more works in the database analyzed.

Tabla 7. Authors with more scientific production.

\begin{tabular}{|l|c|c|c|}
\hline \multirow{2}{*}{ Author } & \multicolumn{2}{|c|}{ Combination } & \\
\cline { 2 - 4 } & L.A. + Higher Education & L.A. + University & Total \\
\hline Dawson, S. & 12 & 10 & 22 \\
\hline Ebner, M. & - & 6 & 6 \\
\hline Gašević, D. & 8 & - & 8 \\
\hline Guenaga, M. & - & 7 & 7 \\
\hline Ifenthaler, D. & 8 & 7 & 15 \\
\hline Kailanto, M. & - & 6 & 6 \\
\hline Lonn, S & 7 & - & 7 \\
\hline Pardo, A. & - & 7 & 7 \\
\hline Prinsloo, P. & 8 & - & 8 \\
\hline Rienties, B. & - & 13 & 13 \\
\hline Shimada, A. & - & 6 & 6 \\
\hline Slade, S. & 7 & - & 7 \\
\hline Teasley, S.D. & 6 & - & 6 \\
\hline
\end{tabular}

The following table presents the results of the institutions that have the highest concentration of scientific production on the topic studied.

Table 8. Institutions.

\begin{tabular}{|l|c|c|c|}
\hline \multirow{2}{*}{\multicolumn{1}{|c|}{ Institution }} & \multicolumn{2}{c|}{ Combination } & \\
\cline { 2 - 4 } & L.A. + Higher Education & L.A. + University & Total \\
\hline Central Queensland University & - & 6 & 6 \\
\hline Covenant University & - & 7 & 7 \\
\hline Curtin University & 12 & 12 & 24 \\
\hline Ewha Womans University & - & 6 & 6 \\
\hline Griffith University & 6 & - & 6 \\
\hline Kyushu University & - & 9 & 9 \\
\hline Macquarie University & 9 & 6 & 15 \\
\hline Open University & 19 & 28 & 47 \\
\hline Tampere University of Technology & - & 7 & 7 \\
\hline Technische Universitat Graz & - & 6 & 6 \\
\hline The University of Sydney & 6 & 12 & 18 \\
\hline Universidad Carlos III de Madrid & - & 6 & 6 \\
\hline
\end{tabular}




\begin{tabular}{|l|c|c|c|}
\hline \multirow{2}{*}{\multicolumn{1}{c|}{ Institution }} & \multicolumn{2}{c|}{ Combination } & \\
\cline { 2 - 4 } & L.A. + Higher Education & L.A. + University & Total \\
\hline Universidad de Deusto & - & 7 & 7 \\
\hline Universidad de Leon & - & 6 & 6 \\
\hline Universidad de Vigo & - & 6 & 6 \\
\hline Universitat Mannheim & 8 & 10 & 18 \\
\hline Universitat Oberta de Catalunya & - & 7 & 7 \\
\hline University of Edinburgh & 11 & - & 11 \\
\hline University of Melbourne & 7 & 6 & 13 \\
\hline University of Michigan, Ann Arbor & 10 & 13 & 23 \\
\hline University of South Africa & 10 & - & 10 \\
\hline University of South Australia & 12 & 13 & 25 \\
\hline University of Southampton & - & 6 & 6 \\
\hline University of Southern & - & 7 & 7 \\
Queensland & - & 7 & 7 \\
\hline University of Wollongong & - & & \\
\hline
\end{tabular}

Considering the country variable, in Table 9 we present those regions that have produced the highest scientific production on learning analytics in higher education.

Table 9. Country.

\begin{tabular}{|c|c|c|c|}
\hline \multirow[t]{2}{*}{ Country } & \multicolumn{2}{|c|}{ Combination } & \multirow[b]{2}{*}{ Total } \\
\hline & L.A. + Higher Education & L.A. + University & \\
\hline Australia & 70 & 87 & 157 \\
\hline Austria & - & 6 & 6 \\
\hline Canada & 10 & 12 & 22 \\
\hline China & - & 20 & 20 \\
\hline Colombia & 7 & 7 & 14 \\
\hline Czech Republic & - & 6 & 6 \\
\hline Ecuador & 6 & - & 6 \\
\hline Finland & - & 12 & 12 \\
\hline France & - & 6 & 6 \\
\hline Germany & 16 & 29 & 45 \\
\hline Greece & - & 10 & 10 \\
\hline Hong Kong & 7 & 9 & 16 \\
\hline Ireland & - & 6 & 6 \\
\hline Italy & - & 11 & 11 \\
\hline Japan & 7 & 17 & 24 \\
\hline Netherlands & 10 & 12 & 22 \\
\hline Nigeria & - & 7 & 7 \\
\hline Portugal & 7 & - & 7 \\
\hline Saudi Arabia & 6 & - & 6 \\
\hline South Africa & 15 & 8 & 23 \\
\hline South Korea & - & 7 & 7 \\
\hline Spain & 28 & 64 & 92 \\
\hline Taiwan & - & 7 & 7 \\
\hline United Arab Emirates & 7 & - & 7 \\
\hline United Kingdom & 57 & 67 & 124 \\
\hline United States & 67 & 75 & 142 \\
\hline
\end{tabular}




\section{INTERNATIONAL JOURNAL OF EDUCATIONAL RESEARCH AND INNOVATION \\ REVISTA INTERNACIONAL DE INVESTIGACIÓN EINNOVACIÓN EDUCATIVA}

Pilar Cáceres, Antonio-Manuel Rodríguez, Gerardo Gómez y Carmen Rodríguez. Analíticas de aprendizaje en educación superior...

Regarding the type of document, in the following table they are presented classified according to the combination used and the type of document analyzed: article, conference paper, review in congress, article in press, among others.

Table 10. Document type.

\begin{tabular}{|l|c|c|c|}
\hline \multirow{2}{*}{ Document type } & \multicolumn{2}{|c|}{ Combination } & \\
\cline { 2 - 4 } & L.A. + Higher Education & L.A. + University & Total \\
\hline Conference Paper & 157 & 248 & 405 \\
\hline Article & 110 & 180 & 290 \\
\hline Book Chapter & 24 & 27 & 51 \\
\hline Conference Review & 23 & 20 & 43 \\
\hline Article in Press & 8 & 9 & 17 \\
\hline Review & 5 & 3 & 8 \\
\hline Book & 4 & 3 & 7 \\
\hline Editorial & 2 & - & 2 \\
\hline Erratum & 1 & - & 1 \\
\hline
\end{tabular}

In line with the previous result, the following table presents the results based on the source type of the researches analyzed.

Table 1: Source type.

\begin{tabular}{|l|c|c|c|}
\hline \multirow{2}{*}{ Source type } & \multicolumn{2}{c|}{ Combinación } & \\
\cline { 2 - 4 } & L.A. + Higher Education & L.A. + University & Total \\
\hline Conference Proceedings & 136 & 228 & 364 \\
\hline Journals & 127 & 192 & 319 \\
\hline Book Series & 47 & 49 & 96 \\
\hline Books & 24 & 20 & 44 \\
\hline Trade Publications & - & 2 & 2 \\
\hline
\end{tabular}

Table 12 shows the different publication areas where research on higher education learning analytics has been researched.

\begin{tabular}{|l|c|c|c|}
\hline \multirow{2}{*}{ Subject area } & \multicolumn{2}{c|}{ Combinación } & \\
\cline { 2 - 4 } & L.A.+ Higher Education & L.A. + University & Total \\
\hline Agricultural and Biological Sciences & - & 1 & 1 \\
\hline Arts and Humanities & 13 & 18 & 31 \\
\hline Biochemistry, Genetics and Molecular Biology & 1 & 2 & 3 \\
\hline Business, Management and Accounting & 15 & 11 & 26 \\
\hline Chemical Engineering & - & 2 & 2 \\
\hline Chemistry & - & 3 & 3 \\
\hline Computer Science & 237 & 339 & 576 \\
\hline Decision Sciences & 18 & 31 & 49 \\
\hline Denistry & 1 & 1 & 2 \\
\hline Economics, Econometrics and Finance & 5 & 3 & 8 \\
\hline Energy & - & 1 & 1 \\
\hline Engineering & 40 & 80 & 120 \\
\hline Environmental Science & 1 & 1 & 2 \\
\hline Health Professions & 1 & 1 & 2 \\
\hline
\end{tabular}




\section{INTERNATIONAL JOURNAL OF EDUCATIONAL \\ RESEARCH AND INNOVATION \\ REVISTA INTERNACIONAL DE INVESTIGACIÓN \\ EINNOVACIÓN EDUCATIVA}

Pilar Cáceres, Antonio-Manuel Rodríguez, Gerardo Gómez y Carmen Rodríguez. Analíticas de aprendizaje en educación superior...

\begin{tabular}{|l|c|c|c|}
\hline \multirow{2}{*}{ Subject area } & \multicolumn{2}{|c|}{ Combinación } & \\
\cline { 2 - 4 } & L.A. + Higher Education & L.A. + University & Total \\
\hline Inmunology and Microbiology & 1 & - & 1 \\
\hline Materials Science & 1 & 3 & 4 \\
\hline Mathematics & 50 & 50 & 100 \\
\hline Medicine & 5 & 4 & 9 \\
\hline Multidisciplinary & - & 7 & 1 \\
\hline Neuroscience & - & 1 & 1 \\
\hline Nursing & - & 1 & 4 \\
\hline Physics and Astronomy & 2 & 2 & 32 \\
\hline Psychology & 15 & 17 & 438 \\
\hline Social Sciences & 179 & 259 & 7 \\
\hline
\end{tabular}

Regarding the language of publication, a scientific production stands out that, predominantly, is written in English (98.29\%), as we can see below:

Table 3: Language.

\begin{tabular}{|l|c|c|c|}
\hline \multirow{2}{*}{ Language } & \multicolumn{2}{|c|}{ Combinación } & \\
\cline { 2 - 4 } & L.A. + Higher Education & L.A. + University & Total \\
\hline Chinese & 1 & - & 2 \\
\hline English & 329 & 478 & 807 \\
\hline German & 1 & 1 & 2 \\
\hline Portuguese & 2 & 2 & 4 \\
\hline Spanish & 3 & 9 & 12 \\
\hline Turkish & - & 1 & 1 \\
\hline
\end{tabular}

Finally, we present the ten most cited articles and greatest impact generated by the scientific community distinction between search equations used.

Table 4. Most cited papers -L.A. AND Higher Education.

\begin{tabular}{|l|c|}
\hline \multicolumn{1}{|c|}{ Reference } & N \\
\hline $\begin{array}{l}\text { Slade, S., \& Prinsloo, P. (2013). Learning analytics: Ethical issues and dilemmas. American Behavioral } \\
\text { Scientist, 57(10), 1510-1529. }\end{array}$ & 140 \\
\hline $\begin{array}{l}\text { Picciano, A. G. (2012). The evolution of big data and learning analytics in American higher } \\
\text { education. Journal of Asynchronous Learning Networks, 16(3), 9-20. }\end{array}$ & 103 \\
\hline $\begin{array}{l}\text { Macfadyen, L. P., \& Dawson, S. (2012). Numbers are not enough. Why e-learning analytics failed to } \\
\text { inform an institutional strategic plan. Journal of Educational Technology \& Society, 15(3), 149-163. }\end{array}$ & 96 \\
\hline $\begin{array}{l}\text { Dietz-Uhler, B., \& Hurn, J. E. (2013). Using learning analytics to predict (and improve) student success: } \\
\text { A faculty perspective. Journal of Interactive Online Learning, 12(1), 17-26. }\end{array}$ & 78 \\
\hline $\begin{array}{l}\text { Yousef, A. M. F., Chatti, M. A., Schroeder, U., \& Wosnitza, M. (2014, July). What drives a successful } \\
\text { MOOC? An empirical examination of criteria to assure design quality of MOOCs. In Advanced Learning }\end{array}$ & 62 \\
Technologies (ICALT), 2014 IEEE 14th International Conference on (pp. 44-48). IEEE. & \\
\hline
\end{tabular}




\begin{tabular}{|l|c|}
\hline \multicolumn{1}{|c|}{ Reference } & $\mathbf{N}$ \\
\hline $\begin{array}{l}\text { Ifenthaler, D., \& Widanapathirana, C. (2014). Development and validation of a learning analytics } \\
\text { framework: Two case studies using support vector machines. Technology, Knowledge and } \\
\text { Learning, 19(1-2), 221-240. }\end{array}$ & 42 \\
\hline $\begin{array}{l}\text { Barber, R., \& Sharkey, M. (2012, April). Course correction: Using analytics to predict course success. } \\
\text { In Proceedings of the 2nd international conference on learning analytics and knowledge (pp. 259-262). } \\
\text { ACM. }\end{array}$ & 39 \\
\hline $\begin{array}{l}\text { Pursel, B. K., Zhang, L., Jablokow, K. W., Choi, G. W., \& Velegol, D. (2016). Understanding MOOC } \\
\text { students: motivations and behaviours indicative of MOOC completion. Journal of Computer Assisted } \\
\text { Learning, 32(3), 202-217. }\end{array}$ & 31 \\
\hline $\begin{array}{l}\text { Mattingly, K. D., Rice, M. C., \& Berge, Z. L. (2012). Learning analytics as a tool for closing the } \\
\text { assessment loop in higher education. Knowledge Management \& E-Learning, 4(3), 236. }\end{array}$ & 30 \\
\hline $\begin{array}{l}\text { Drachsler, H., \& Greller, W. (2012, April). The pulse of learning analytics understandings and expectations } \\
\text { from the stakeholders. In Proceedings of the 2nd international conference on learning analytics and } \\
\text { knowledge (pp. 120-129). ACM. }\end{array}$ & 30 \\
\hline
\end{tabular}

Table 5. Most cited papers - L.A. AND UNIVERSITY.

\begin{tabular}{|c|c|}
\hline Refe & $\mathbf{N}$ \\
\hline $\begin{array}{l}\text { Macfadyen, L. P., \& Dawson, S. (2012). Numbers are not enough. Why e-learning analytics failed to } \\
\text { inform an institutional strategic plan. Journal of Educational Technology \& Society, 15(3), 149-163. }\end{array}$ & 96 \\
\hline $\begin{array}{l}\text { Gasevic, D., Kovanovic, V., Joksimovic, S., \& Siemens, G. (2014). Where is research on massive open } \\
\text { online courses headed? A data analysis of the MOOC Research Initiative. The International Review of } \\
\text { Research in Open and Distributed Learning, } 15(5) \text {. }\end{array}$ & 86 \\
\hline $\begin{array}{l}\text { Ferguson, R., \& Shum, S. B. (2012, April). Social learning analytics: five approaches. In Proceedings of } \\
\text { the 2nd international conference on learning analytics and knowledge (pp. 23-33). ACM. }\end{array}$ & 73 \\
\hline $\begin{array}{l}\text { Baker, R. S., \& Inventado, P. S. (2014). Educational data mining and learning analytics. In Learning } \\
\text { analytics (pp. 61-75). Springer, New York, NY. }\end{array}$ & 72 \\
\hline $\begin{array}{l}\text { Coffrin, C., Corrin, L., de Barba, P., \& Kennedy, G. (2014, March). Visualizing patterns of student } \\
\text { engagement and performance in MOOCs. In Proceedings of the fourth international conference on } \\
\text { learning analytics and knowledge(pp. 83-92). ACM. }\end{array}$ & 70 \\
\hline $\begin{array}{l}\text { Wolff, A., Zdrahal, Z., Nikolov, A., \& Pantucek, M. (2013, April). Improving retention: prec } \\
\text { students by analysing clicking behaviour in a virtual learning environment. In Proceeding } \\
\text { international conference on learning analytics and knowledge (pp. 145-149). ACM. }\end{array}$ & 52 \\
\hline $\begin{array}{l}\text { Watson, C., Li, F. W., \& Godwin, J. L. (2013, July). Predicting performan } \\
\text { programming course by logging and analyzing student programming be } \\
\text { International Conference on Advanced Learning Technologies (ICALT) ( }\end{array}$ & 47 \\
\hline $\begin{array}{l}\text { Gašević, D., Zouaq, A., \& Janzen, R. (2013). "Choose your classmates, your GPA is at stake!" The } \\
\text { association of cross-class social ties and academic performance. American Behavioral Scientist, } 57(10) \text {, } \\
1460-1479 .\end{array}$ & 44 \\
\hline $\begin{array}{l}\text { Ferguson, R., \& Clow, D. (2015, March). Examining engagement: analysing learner subpopulations in } \\
\text { massive open online courses (MOOCs). In Proceedings of the Fifth International Conference on Learning } \\
\text { Analytics And Knowledge (pp. 51-58). ACM. }\end{array}$ & 40 \\
\hline $\begin{array}{l}\text { Barber, R., \& Sharkey, M. (2012, April). Course correction: Using analytics to predict cour } \\
\text { In Proceedings of the } 2 \text { nd international conference on learning analytics and knowledg } \\
\text { ACM. }\end{array}$ & 39 \\
\hline
\end{tabular}




\section{Discusion y Conclusions.}

The objective of this article was to analyze the scientific production with the greatest impact on learning analytics in the field of higher education. Its main contribution is determined by the outline of the panorama of research on this practice at an international level. At this time, it should be noted that no similar studies have been conducted on this subject, but the one presented here follows the line of other studies of a similar nature, such as those carried out by López-Meneses, Vázquez-Cano \& Román, 2015; Mengual-Andrés, Vázquez-Cano \& López-Meneses, 2017; or Rodríguez-García, Cáceres, \& Alonso, 2018.

In this way, once the investigation is carried out, we proceed to capture the main conclusions we have reached:

- Research begins to be indexed in the database from the year 2010. From that moment, we can observe a phase of progressive growth whose maximum exponent is concentrated between the years 2015-2018. These results confirm the hypothesis that the learning analytics are an emerging trend in the field of higher education (Johnson et al., 2016; Slade y Prinsloo, 2013).

- Within the periodical publications, we highlight The ACM International Conference, for concentrating $13 \%$ of the scientific production analyzed.

- We found an increasing scientific production of Shane Dawson (Director of the Teaching Innovation Unit and Professor of Learning Analytics at the University of South Australia) and Dirk Ifenthaler (Deakin University Melbourne, Australia).

- aking into account the variable that relates the quantity of publications with the signatory institutions, a greater scientific production of the Open University, Milton Keynes (United Kingdom), the University of South Australia (Australia), Curtin University (Australia) and the University of Michigan, Ann Arbor stands out.

- Australia is the country, in general, with the highest scientific production (19.12\%), followed by the United States (17,3\%) and United Kingdowm (15,1\%).

- The vast majority of the publications analyzed are conference paper (49.33\%). In second place are the articles $(35,32 \%)$. In an intermediate position are the book chapter $(6.21 \%)$ and conference review (5.23\%).

- Logically, in line with the previous result, most of the research is published in conferrence proceedings (44.34\%) and journals (38.86\%). To a lesser extent we find book series (11.69\%), books (5.35\%) and Trade Publications $(0.24 \%)$.

- Regarding to the subject area, most of the investigations are indexed in computer science $(70.16 \%)$. Second, the Social Sciences area occupies a relevant position, bringing together $53.34 \%$ of the research found.

- Predominantly, in its vast majority, a research published in English (98.3\%).

- Due to the importance of their work in the area under investigation, it is worth mentioning those carried out by Baker \& Inventado (2014), Coffrin, Corrin, by Barba \& Kennedy (2014), Dietz-Uhler \& Hurn (2013), Ferguson \& Shum (2012) Gasevic, Kovanovic, Joksimovic \& Siemens (2014), Macfadyen \& Dawson (2012) Picciano (2012), Slade and Prinslo (2013), Yousef et al. (2014). 
In short, we see a research landscape that has grown exponentially in recent years. Although the largest research focus is in Australia, large numbers of researchers from countries in different parts of the world are showing a growing interest in learning analytics in the field of higher education. So, we bet that, very possibly, in the coming years this practice will have achieved a greater educational setting and will be used for the improvement of the teaching-learning processes, the results of the students, the teachers and, ultimately, the quality of education and of the institution itself (Gedrimiene et al., 2019).

\section{Financing}

Ministry of Education, Culture and Sport through the Aid of the University Teaching Staff Training Program (F.P.U). Reference FPU14/04626.

\section{Bibliographic references}

- Antelm, A. M., Gil. A., Cacheiro, M.L. y Pérez, E. (2018). Causas del fracaso escolar: un análisis desde la perspectiva del profesorado y el alumnado. Enseñanza \& Teaching, 36(1), 129-149.

- Alonso-García, S., Rodríguez-García, A. M., \& Cáceres-Reche, M. (2018). Análisis de la Acción Tutorial y su Incidencia en el Desarrollo Integral del Alumnado. El Caso de la Universidad de Castilla La Mancha, España. Formación universitaria, 11(3), 63-72.

- Baker, R. S., \& Inventado, P. S. (2014). Educational data mining and learning analytics. In Learning analytics (pp. 61-75). Springer, New York, NY.

- Cabedo, A., Galán, M.E. \& Gómez, N. (2018). UniTICarte: Redes Colaborativas para el desarrollo de proyectos creativos en la formación de Maestros en la Universidad. Dedica. Revista de Educação e Humanidades, 12, 119-129.

- Chiappe, A., \& Rodríguez, L. P. (2017). Learning Analytics in 21st century education: a review. Ensaio: Avaliação e Políticas Públicas em Educação, 25(97), 971-991.

- Coffrin, C., Corrin, L., de Barba, P., \& Kennedy, G. (2014, March). Visualizing patterns of student engagement and performance in MOOCs. In Proceedings of the fourth international conference on learning analytics and knowledge (pp. 83-92). ACM.

- Dietz-Uhler, B., \& Hurn, J. E. (2013). Using learning analytics to predict (and improve) student success: A faculty perspective. Journal of Interactive Online Learning, 12(1), 1726.

- Ferguson, R., \& Shum, S. B. (2012, April). Social learning analytics: five approaches. In Proceedings of the 2nd international conference on learning analytics and knowledge (pp. 23-33). ACM.

- Gasevic, D., Kovanovic, V., Joksimovic, S., \& Siemens, G. (2014). Where is research on massive open online courses headed? A data analysis of the MOOC Research Initiative. The International Review of Research in Open and Distributed Learning, 15(5), 134-176.

- Gedrimiene, E., Silvola, A., Pursiainen, J., Rusanen, J., \& Muukkonen, H. (2019). Learning Analytics in Education: Literature Review and Case Examples From Vocational Education. Scandinavian Journal of Educational Research, 1-15.

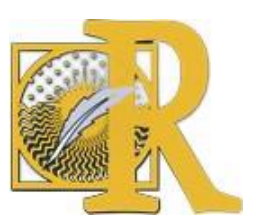


- Johnson, L., Becker, S. A., Cummins, M., Estrada, V., Freeman, A., \& Hall, C. (2016). NMC horizon report: 2016 higher education edition (pp. 1-50). The New Media Consortium.

- Hernández Sampieri, R., Fernández Collado, C. \& Baptista Lucio, P. (2016). Metodología de la investigación (6ª Edición). México: MC Graw Hill Education.

- Hinojo-Lucena, F., Mingorance-Estrada, Á., Trujillo-Torres, J., Aznar-Díaz, I., \& Cáceres Reche, M. (2018). Incidence of the Flipped Classroom in the Physical Education Students' Academic Performance in University Contexts. Sustainability, 10(5), 1334.

- Huda, M., Maseleno, A., Atmotiyoso, P., Siregar, M., Ahmad, R., Jasmi, K., \& Muhamad, N. (2018). Big data emerging technology: insights into innovative environment for online learning resources. International Journal of Emerging Technologies in Learning (iJET), 13(1), 23-36.

- Klein, C., Lester, J., Rangwala, H., \& Johri, A. (2019). Technological barriers and incentives to learning analytics adoption in higher education: insights from users. Journal of Computing in Higher Education, 1-22.

- López-Meneses, E., Vázquez-Cano, E., \& Román, P. (2015). Análisis e implicaciones del impacto del movimiento MOOC en la comunidad científica: JCR y Scopus (2010- 13). Comunicar: Revista científica iberoamericana de comunicación y educación, 22(44), 7380. DOI: http://dx.doi.org/10.3916/C44-2015-08

- Macfadyen, L. P., \& Dawson, S. (2012). Numbers are not enough. Why e-learning analytics failed to inform an institutional strategic plan. Journal of Educational Technology \& Society, 15(3),149-163.

- Mengual-Andrés, S., Vázquez-Cano, E., \& López-Meneses, E. (2017). La productividad científica sobre MOOC: aproximación bibliométrica 2012-2016 a través de SCOPUS. RIED. Revista Iberoamericana de Educación a Distancia, 20(1), 39-58.

- Picciano, A. G. (2012). The evolution of big data and learning analytics in American higher education. Journal of Asynchronous Learning Networks, 16(3), 9-20.

- Siemens, G. (2012, April). Learning analytics: envisioning a research discipline and a domain of practice. In Proceedings of the 2nd international conference on learning analytics and knowledge (pp. 4-8). ACM.

- Long, P., \& Siemens, G. (2014). Penetrating the fog: analytics in learning and education. Italian Journal of Educational Technology, 22(3), 132-137.

- Mingorance, A. C., Trujillo, J. M., Cáceres, P., \& Torres, C. (2017). Mejora del rendimiento académico a través de la metodología de aula invertida centrada en el aprendizaje activo del estudiante universitario de ciencias de la educación. Journal of sport and health research, 9(1), 129-136.

- Montgomery, A. P., Mousavi, A., Carbonaro, M., Hayward, D. V., \& Dunn, W. (2019). Using learning analytics to explore self-regulated learning in flipped blended learning music teacher education. British Journal of Educational Technology, 50(1), 114-127. 
- Moreira, A., Bates, T., \& Mota, J. (2019). What future (s) for distance education universities? Towards an open network-based approach/ ¿Qué futuro para las universidades de educación a distancia? Hacia un enfoque abierto basado en la red. RIED. Revista Iberoamericana de Educación a Distancia, 22(1), 107-126.

- Rodríguez-García, A. M., Cáceres, M. P., \& Alonso, S. (2018). The digital competence of the future teacher: bibliometric analysis of scientific productivity indexed in Scopus. IJERI: International Journal of Educational Research and Innovation, 10, 317-333.

- Slade, S., \& Prinsloo, P. (2013). Learning analytics: Ethical issues and dilemmas. American Behavioral Scientist, 57(10), 1510-1529.

- Ulstad, S. O., Halvari, H., \& Deci, E. L. (2018). The Role of Students' and Teachers' Ratings of Autonomous Motivation in a Self-Determination Theory Model Predicting Participation in Physical Education. Scandinavian Journal of Educational Research, 1-16.

- Urrutia, G., y Bonail, X. (2010). Declaración PRISMA: una propuesta para mejorar la publicación de revisiones sistemáticas y metaanálisis. Medicina Clínica, 135(11), 507511.

- Wong, B. T. M., \& Li, K. C. (2019). A review of learning analytics intervention in higher education (2011-2018). Journal of Computers in Education, 1-22.

- Yousef, A. M. F., Chatti, M. A., Schroeder, U., \& Wosnitza, M. (2014, July). What drives a successful MOOC? An empirical examination of criteria to assure design quality of MOOCs. In Advanced Learning Technologies (ICALT), 2014 IEEE 14th International Conference on (pp. 44-48). IEEE. 